\title{
Sustainable Water Service Delivery: An Assessment of a Water Agency in a Rapidly Urbanizing City in Nigeria
}

\author{
A.E. Olajuyigbe \\ Department of Urban and Regional Planning, Federal University of Technology \\ P.M.B. 704, Akure, Nigeria \\ Tel: 234-803-711-7606, 234-805-554-0050_E-mail: olajuyigbe03@yahoo.com
}

\begin{abstract}
In the Nigerian Federation, water supply is a state responsibility. State governments have therefore created State Water Agencies to manage and operate systems for water service delivery in all urban and semi-urban areas. Generally, these State Water Agencies have failed to effectively deliver water services to the people. In Ado-Ekiti, the Ekiti State Water Corporation is saddled with the task of meeting the water needs of the city dwellers. This paper examines some factors that explain the poor service delivery level of the Corporation. Adopting a sample size of 1,200 ( $4 \%$ of the total number of households in Ado-Ekiti) through random sampling technique, empirical estimates show that factors that significantly affect the performance level of this Corporation include: payment for water supply, billing system, adequacy of supply, frequency of pumping of water, notices from the Corporation in cases of system breakdown, response to leakages, adequacy of public standing pipes and appropriate location or distribution of standing pipes. The paper clamored for an evolvement of water policy for the state that would adequately address the issues emanating from the significant factors affecting the Corporation performance.
\end{abstract}

Keywords: Ekiti State Water Corporation, Performance level, Water pricing, Water policy, Private sector intervention

\section{Introduction}

Nigeria has an estimated Total Actual Renewable Water Resources (TARWR) of $286.2 \mathrm{~km}^{3} /$ year amounting to 1 $893 \mathrm{~m}^{3} /$ year per capital (AQUASTAT FAO, 2010). This is no doubt a great resource which should be harnessed to produce maximum benefit to the nation. In an attempt to maximize this potential, a number of agencies have been put in place for the management of water resources and provision of water services infrastructure in the country. At the Federal level, there is the Federal Ministry of Water Resources with mandate for development of overall policy and regulatory mechanism for water development and utilization. In the country, water supply is a state responsibility. Towards this end, state governments have created State Water Agencies (SWAs) - Water Boards and Water Corporations - to manage and operate systems for water service delivery in all urban and semi-urban areas. The Nigerian Water Policy indicates that water should be regarded as an economic good as well as social services and encourages the autonomy of SWAs.

Paradoxically, irrespective of the abundant natural water resources, proliferation of water works in the country coupled with a robust policy that spells out strategies and attainable targets, the water situation in Nigeria could best be described as precarious. Over the years, improvement in domestic water supply has not been impressive. For example, in $1990,47 \%$ of Nigerians have access to improved water. This percentage increased slightly to $53 \%$ in 1990. Displaying similar growth rate, only $58 \%$ access was recorded in 2008 (WHO/UNICEF JMP, 2010). In rural areas, where the majority of Nigerians live, only 58\% had access in 2008 (WHO/UNICEF JMP, 2010). The absurdity in water supply situation in Nigeria is further revealed by the fact that urban domestic water supply has been on decline since 1990. For example in 1990, 79\% of the urban dwellers had access. This decreases to $77 \%$ and $75 \%$ in 2000 and 2008 respectively (WHO/UNICEF JMP, 2010). In literature, piped water is often equated to safe water since improved sources could still contain some harmful substances (Sulllivan et al, 2003). Therefore, access to piped water is regarded as a measure of access to safe water. It is pathetic to observe that access to piped water among Nigerians has decreased extensively from $14 \%$ in 1990 to $6 \%$ in 2008 (WHO/UNICEF JMP, 2010).

In the developing countries where the development of water is mostly government-driven, failure to develop efficient water supply systems has been established as a product of the interplay of several factors. Among them, securing finances to build, maintain and expand the systems is perhaps the most important (UNEP, 2002; Hall 2006). The availability of finance especially for day-to-day operations and maintenance is significant in view of the low level of public finances for urban development, including water supply (World Bank, 1994; Urban Age, 1993). In general, water supply in these countries is undertaken by government parastatals that have the dual objectives of providing a social service while generating revenue to offset cost. Ironically, most of these parastatals do not recover their operating expenses from their own revenues, and remain dependent on state governments for subsidies (Hall, 2006). Studies also confirmed that about half the water in drinking water supply systems in the developing world is lost to leakage, illegal hook-ups and vandalism (UN, 2002; Hall, 2006). In addition, lack of clear institutional objectives, low wages and poor equipment and supplies have been widely cited as the typical institutional characteristics of water supply agencies in the developing countries (World Bank, 
1994; Franceys, 1993). Performance assessments of these institutions typically reveal weaknesses including low output performance, ineffective delivery system and poor financial portfolio.

Water supply in Nigeria most vividly reflects the above scenario. The country has 37 SWAs and 12 River Basin Development Authorities (RBDAs). Several of these water agencies and authorities depend on obsolete water equipments. This has been largely due to poor investments by Government and private sector organizations in the water sector in the last ten years in Nigeria compared to other sectors such as oil and gas, energy, housing among others (Adoga, 2006). These agencies lack capacity and financial resources and so are finding it difficult to meet the existing demand for safe water within their respective areas (Hall, 2006). Although, the problem of funding is a global bane on the development of the water sector, however, the Nigeria situation is deplorable considering the high level of poverty, inadequate Government funding, and weak private participation (Adoga, 2006). The financial portfolio of these agencies is further worsened by the low proportion of water users that pay for water services. For example, in Lagos, Nigeria, only $4 \%$ of water users pay their bills (Hall, 2006). In addition, leakage rates are estimated to be about $50 \%$ while the proportion lost to wastage and illegal connections is actually rising (Hall, 2006). Extensive areas in many cities in the country do not have any network connections. Again, the bane of Nigerian water sector could be traced to demographic and economic antecedents. While the government could no longer cope with the huge financial resources required for both system maintenance and expansion, the country's population continues to increase unabated. Specifically, adequate public funds are no longer available for extending either coverage or service levels in terms of per capita use.

To supplement the inadequacy arising from the failure of the public water systems at meeting the soaring need of the populace, alternative sources are often sought. These include wells, boreholes, surface water, tanker-drawn water, rain water among others. In most cases, these sources are often expensive or unsafe for human consumption (Ademola and Afeikhena, 2006). It has been established that the incidence of most diseases could be linked directly to this problem (WHO and UNICEF, 2004). The public water supply system itself is riddled with so much leakage that high levels of bacteriology contamination occur. This makes the piped supply system hardly safer than the wells (Dada, et al, 1990).

This research presents empirical estimates (regression elasticities) of some factors that influence the performance of the State Water Agency (SWA) with respect to water service delivery in Ado-Ekiti, a rapidly urbanizing city in Nigeria. An understanding of these factors will definitely enhance the formulation of policy aimed at ensuring the development of improved and sustainable water system in Ado-Ekiti and other cities not only in Nigeria but other developing countries of the World.

\section{Materials and Methods}

\subsection{Research Locale}

The study area is Ado-Ekiti. It is located in the south west of Nigeria (Fig. 1). Following the creation of Ekiti state on October 1, 1996, Ado-Ekiti became a capital city. The city lies entirely within the pre-Cambrian Basement complex rock group which underlies most south western part of Nigeria. Due to its peculiar gneisses formation with small aquifers and relatively shallow overburden, Ado-Ekiti is poor in groundwater potentials (Fadipe and Adeduro, 1993; Ebisemiju, 1993). These peculiarities result into low yield situation of boreholes in this city while most wells often dry up during dry season. Ado-Ekiti experiences a tropical climate with distinct wet and dry seasons. These seasons are associated with the prevalence of maritime south westerly monsoon winds from the Atlantic Ocean and the dry continental north easterly harmattan winds from the Sahara Desert. The city therefore enjoys water surplus between May and October with substantial water deficit between November and April when all stream channels are completely dry while the main rivers are reduced to a chain of pools (Ebisemiju, 1993).

The responsibility for the supply of potable water to the city is assigned by government to Ekiti State Water Corporation (EKSWC). This mandate is to be met through a supply from Ureje Dam, Ado-Ekiti, a dam that was commissioned in 1962 . With a design capacity of $4,950 \mathrm{~m}^{3}$ per day on commissioning, the current capacity utilization of the dam still remains at $95 \%$. Again, the initial pipe network coverage has hardly been extended since commissioning. The coverage presently is the city core (Fig. 2). With an estimated population of 209,866 (Ekiti State Department of Population Activities,2004), Ado Township needs about $16,000 \mathrm{~m}^{3}$ of water supply everyday, but the town receives only $750 \mathrm{~m}^{3}$ daily. There is therefore an obvious gap between the water supply from Ureje Dam and water need in this growing city. Most people therefore rely on other sources of supply, such as wells, streams and rivers and supplies from vendors among others that are often highly contaminated or in most cases inadequate to meet the hygiene requirements. The obvious implication of this is that there had been an insufficient investment on system expansion and maintenance.

Again, in this city, government intervention has kept water rates and charges low for political reasons, under the assumption that the majority of the population would not accept higher charges. As a consequence, accrued revenue from operations could only cover a small fraction of recurrent expenditure. The implication of this is that the EKSWC is a state owned enterprise that has to comply with social objectives, without getting the means to do so. 


\subsection{Database description}

As the main thrust of this research, the study was interested in the analysis of the spatial variation in water supply and demand systems in Ado Ekiti. To achieve this, three residential zones were identified in the city. They include; the urban core, transitional zone and urban periphery (Fig. 2). A basic assumption made with respect to the populations of these zones was that fifty percent $(50 \%)$ of the total population live in the city core while thirty five percent $(35 \%)$ and fifteen percent $(15 \%)$ live in the peripheral neighborhood to the core and the suburb respectively.

The projected population figure for Ado-Ekiti in 2006 was put at 209,866 (Ekiti State Department of Population Activities, 2004). Average family size in Nigeria has been estimated at 7 (Fasakin, 2000). This implies that there were about 29,981 households in Ado-Ekiti. For this research, a sample size of 1,200 amounting to 4.0\% of the total number of households in Ado-Ekiti was chosen. This appears plausible since there are traits of homogeneity in habitability in this study area.

Having stratified the city into three zones, specific areas that are convenient for data collection otherwise referred to in this study as Data Delineation Areas (DDAs) were identified in each zone. Based on the estimated population of each DDA, the number of households to be interviewed was estimated. In consonance with our earlier assumptions, $600(50 \%)$ questionnaires were administered in the city core while $420(35 \%)$ and 180 (15\%) questionnaires were administered in the transitional zone and urban periphery respectively. Subsequently, systematic sampling procedure was adopted in the choice of households to be interviewed in each DDA. Fieldwork commenced in September 2007 and ended in December 2008. The survey utilized 22 variables out of which 9 were selected for multivariate analysis (Appendix A). Table 1 shows the variables used in constructing a model for factors influencing the performance of the EKSWC with respect to water delivery in Ado-Ekiti.

As a basis for empirical analysis, the specification, rationale and justification for the choice of variables are discussed. The variable of notable interest is PERFORM, which is a direct measure of factors influencing the performance of the EKSWC.

Essentially, this research relies on perception variables to measure the level of service delivery of the EKSWC. Variable PERFORM measures the performance level of the EKSWC. The variable summarizes the failure or otherwise of this Corporation with respect to service delivery.

One of the greatest obstacles confronting sustainable water services has been the token attempts by consumers to pay for water supply. It has been argued that payment for such water consumption could be an important stimulus to the efficient use of water as a resource and a valuable source of revenue to ensure service even to the absolute poor and an assured facility maintenance and expansion (Kalbermatten, 1999; Cairncross, 1990). Therefore, PAY is an attribute that measures the proportion of the consumers that pays for water consumption from the Corporation.

To ensure good and sustainable water supply, it has been suggested that water authorities must establish systems that measure water consumption and then charge according to consumption. This is the principle of cost-reflective pricing (Stiles, 1996). This could only be achieved through metering of such facility. METER is a variable that measures the proportion of the households whose supplies are metered. Experience has however shown that for public utilities, even when they are metered, the bill hardly reflects readings from such meter. BILL is an attribute that investigates whether billing reflects readings from meter in Ado Ekiti.

In Nigeria, hardly does a community exist where pipe-borne water runs ceaselessly. It is also a known fact that in most communities, supplies are often rationed. In this regard, communities or sections of communities have specific number of days when water is supplied to them by the SWAs. Attribute ADE-SUPPLY therefore investigates the adequacy or otherwise of supply while FRE-PUMP measures the reliability of water releases by EKSWC to this city.

NOTICES and RE-LEAK are attributes designed to gauge the responsiveness of the service provider to emergencies. The variables also measure the level of reliability and dependability of the Corporation.

There is definitely a direct correlation between number of public standpipes and adequacy of water supply. Overcrowdings and fights that are often observed around public standpipes are direct consequence of their inadequacy. A-TAP is a variable that measures the adequacy or otherwise of the number of standpipes in the city.

For effectiveness, population concentrations should be a determinant for location of standpipes in a community. Variable L-TAP gauges this assertion in Ado Ekiti. The attribute could also be engaged to measure the extent of water pipe network in the city.

\section{The Model}

The model used in the empirical estimation of parameters of analysis in this study is the logistic (double-log) linear regression function expressed below: 


$$
\ln (Y)=b_{o}+\sum_{i=1}^{n} b_{1} \ln X_{i}
$$

Where $\ln$ is natural logarithm, $\mathbf{b}_{\mathbf{0}}$ is constant, $\mathbf{b}_{1} \ldots \ldots . \mathbf{b}_{\mathbf{n}}$ are the parameter estimates or elasticity estimates or regression coefficients measured on a continuous scale and $\mathbf{X 1}$.... Xn represent the predictor variables.

A number of reasons were considered critical in choosing double log version of the regression model over linear and semi-log models. First, the double log regression model enables the presentation of the regression coefficients directly as elasticity estimates (Fasakin, 2000; Arimah, 1995). Second, it translates the skewness of the data frequency to a normal one thereby enabling much better estimates of the explanatory variable (Fasakin, 2000). Third, it reduces the occurrence of heteroscedasticity, that is, the variance of the distribution of the residual is uniform or constant for all values of the variables of research. Fourth, it ensures the stability of and significance of the implied relationship thereby enabling better explanatory power of the coefficient of multiple determination $\left(\mathrm{R}^{2}\right)$ (Fasakin, 2001 and Arimah, 1995).

The factors that were identified as impacting on the performance of the EKSWC are PAY, BILL, ADE-SUPPLY, FRE-PUMP, NOTICE, RE-LEAK, A-TAP and L-TAP. One of the greatest problems confronting the use of regression models has been the issue of spatial autocorrelation and the problem of two or more variables aligning or having high correlation coefficients between or among themselves otherwise known as collinearity and multi-collinearity (Abumere, 1984 and Fasakin, 2000). The need to eliminate such occurrence in a bid to validate the various estimates from this model is crucial. It therefore became imperative to first test for such inter-correlation among the variables used in the model for this research. The results of this test are displayed in the correlation matrix in table 2. Generally, collinearity or multi-collinearity seriously affects regression coefficients when pair-wise correlation coefficients among independent variables exceed 0.80 (Fasakin, 2001 ). The results indicate that the regression will in no way be affected by either pair-wise collinearity or multi-collinearity since there is no pair-wise correlation in excess of 0.80 among the independent variables. In our own case the highest observed correlation coefficient is 0.573 . This therefore confirms the true independence of and the reliability of the variables and parameter estimates, used in this analysis. Hence, using these variables, the regression equation in this analysis could be presented as follow:

$$
\begin{array}{r}
\ln (\text { PERFORM })=b o+b 1 \ln (\text { PAY })+b 2 \ln (\text { BILL })+b 3 \ln (\text { ADE-SUPPLY })+ \\
\text { b4 } \ln (\text { FRE-PUMP })+b 5 \ln (\text { NOTICE })+b 6 \ln (\text { RE-LEAK })+ \\
\text { b } 7 \ln (\text { A-TAP })+b 8 \ln (\text { L-TAP })
\end{array}
$$

\section{Results and Discussion}

The results of the multiple regression model in table 3 shows some stability and a high influence of estimated parameters in that $80.7 \%$ in the variation in the rating of the performance level of the EKSWC in Ado-Ekiti is accounted for by the variables used in this analysis. Reinforcing this discovery, it was further observed that the coefficients of multiple determination $\left(\mathrm{R}^{2}\right)$ for the city core, transitional zone and urban periphery are even higher than that of the city-wide $\mathrm{R}^{2}$. Specifically, the selected variables wholly $(100 \%)$ account for this variation in the city core while both the transitional zone and urban periphery record $99.90 \%$. The F-ratios show that all the $\mathrm{R}^{2}$ values are significant at 0.000 alpha level.

One observes that the prime factors impacting on the performance of the EKSWC include PAY, BILL, ADE-SUPPLY, FRE-PUMP, RE-LEAK and A-TAP. Expectedly, although these variables affect the performance of the Corporation city-wide and in each of the residential zones, the impacts are mostly significant in the city core. This situation could only be explained by the fact that pipe network and public standpipes are largely restricted to this zone. Households in this zone are therefore in a better position to gauge the performance of the Corporation.

The influence of PAY on the performance of the Corporation city-wide and in the city core has coefficient estimates of 0.402 and 3.367 at 0.01 and 0.001 alpha levels respectively. In essence, it implies that an improvement of the current monthly water rates which range from USD0.07 to USD3.33 for tenement and flatted building provided by the Corporation among households city-wide and in the city core, say by $100 \%$, would lead to $40.2 \%$ and $336.7 \%$ increment in the service delivery by the Corporation to both the city and the city core. This is quite plausible since it has been concluded that for efficient use of water as a resource and a valuable source of revenue that could facilitate system expansion and maintenance, consumers must pay (Kalbermatten, 1999; UNDP, 1998; Franceys, 1993). It was observed that most households having access to supply from EKSWC never pay for such service. Even when payments are made, they are often below USD1.00 per month. Such bills are not realistic. They are definitely not commensurable with the cost of water consumed per person per month which has been estimated at USD24.00 by the Corporation. A reverse in the above scenario would in no doubt bring about the necessary expected improvement in this sector as confirmed by the model. An improvement in water services should not affect negatively, the willingness to pay of the residents, considering the low water rate regime currently in use. 
Closely related to the above factor is BILL. The variable exhibits a parameter estimate of -0.318 that is significant only at the city level. The implication of this finding is that any decrement in the number of households that pay according to the actual bill, say by $100 \%$, will reduce the performance level of the Corporation by $31.8 \%$. This also conforms to apriori expectation since it has been argued that for efficient use of water as a resource, the pricing system must be cost-reflective. This appears to be the only means of maximizing revenues from the Corporation's endeavors. The role of such revenue to system maintenance and expansion is enormous. Investigation revealed that less than $5 \%$ of the supplies are metered. In addition, these meters hardly reflect actual consumption. These practices do not enhance revenue promotion. Any improvement in the billing system is therefore expected to enhance the performance of the Corporation as observed in this model. The billing system must cover at least $60-70 \%$ of the consumers for the water agency to perform.

Another major factor that has negative influence on the performance of the Corporation is ADE-SUPPLY. This factor displays a coefficient estimate of -6.649 at 0.01 alpha level in the city core, meaning that a $100 \%$ reduction in the supply from the Corporation would reduce its performance rating by $664.9 \%$. This is rather expected since what is paramount to households is the adequacy of supply especially when such source is considered relatively "safe". At its present production level, most city dwellers conclude that supply from the Corporation is inadequate. Therefore, a significant improvement in the supply situation would enhance the Corporation's performance rating. The disproportionate rating drop of $664.9 \%$ is a reflection of the water poverty and frustration of the consumers. It is also a mirror of sometimes totally unrealistic bills given to consumers when no service is rendered. It is true that people may not be paying enough, but most of the time they pay for the services not rendered. It is an irony.

A further inspection of the various elasticity estimates shows that variable FRE-PUMP has significant impact on the performance of the EKSWC. With the coefficient of -5.460 in the city core at 0.05 alpha level, it means that a further reduction in the frequency of pumping (water release to the households) by $100 \%$, the performance rating of the Corporation will slump by $546 \%$. Presently, the Corporation releases water once or twice in a week on a diversionary basis. Most households do not consider this situation as pleasing. The paucity of supply from this source and usual long queue around the public stand pipes are the direct consequences of this scenario. An improvement in the frequency of pumping is therefore expected to improve the performance of the Corporation.

The elasticity estimate of variable RE-LEAK is also negatively significant at -2.402 in the city core. This means that given a $100 \%$ reduction in the response rate of the Corporation to pipe leakages, the performance rating will decline by $240.2 \%$. Essentially, this variable measures the level of reliability and dependability of the Corporation. It is a measure of response to emergencies. Leakage constitutes a breakdown in the system. When left for a considerable period of time unattended to, the households suffer from lack of water. Response to such leakages has been adjudged poor by households in Ado-Ekiti. Therefore, an improvement in the Corporation's response to pipe leakages will enhance its performance.

The last factor that significantly affects the performance of the Corporation is A-TAP. It displays a regression estimate of 5.659 in the city core at 0.01 alpha level. The implication of the observed elasticity estimate is that given a further increase in the number of public stand pipes within the city core, the efficiency of the Corporation as a water agency will improve by $565.9 \%$. This is rather expected since all things being equal; the quantity of water that households could access will largely be determined by the number of standing pipes. In a situation where most city dwellers considered the present number of public standing pipes inadequate, an increment in the number of these standing pipes will therefore significantly amplify the performance of the Corporation.

\section{Conclusion and Recommendations}

This paper has specifically highlighted that payment for water supply, the current billing system and adequacy of water supply are the factors affecting the performance of EKSWC. Other factors influencing the Corporation's performance include; breakdowns in pipe network, skewed distribution of standing pipes among others.

The place of policy in any meaningful intervention in the water sector cannot be overemphasized. Without an articulate policy, it becomes difficult to effectively characterize, operate, manage and improve water system. Paradoxically, until the recent past, Nigeria cannot be said to possess an articulate water policy. In like manner, the operation of the State Water Corporation is largely guided by the Corporation's Enabling Edict (now Law) of 1997. This perhaps explains the backlog of problems presently confronting the sector. The need for the state to evolve a well articulate water policy that is capable of addressing these problems is imperative and urgent. The proposed policy must change the notion of free social service attached to water. The reality of appropriate cost-implication of raw water abstraction, treatment, transmission, distribution and other administrative costs makes this change inevitable. In this regards, water must be recognized as an economic good that should attract price. The Law should therefore provide for the adoption of pricing that would be cost-reflective. It is interesting to note that at present, the cost of water consumed per person monthly is USD24.00 while the highest rate paid per household comprising of an average of seven (7) inhabitants is USD3.33. It has been found out that even when subsidies are given, they do not significantly benefit the targeted population. More so, it has been observed 
that most city dwellers often pay far and above the actual market value of water especially during scarcity. The need for the policy to recognize the prime position of the private sector in the water provision to enable it participates in the building of dams, purification and transmission of water to homes becomes therefore apparent. This is in realization that the amount required by government to provide potable water to all is so enormous that it would take a significant proportion of the state government's annual budget.

The over centralized role of the EKSWC in water provision for the city of Ado-Ekiti is counterproductive as the city only relies on a water works. Encouragement of creation of large-scale water distribution centres with adequate reservoirs that would have defined sphere of influence and coverage rather than dependence on a centralized source is desirable. Therefore, the establishment of the reservoirs must be based on needs duly established by scientific process. Given this situation, the city could be divided into Water Supply Areas (WSAs) with each WSA having a large-scale water distribution centre that could meet the water need of each supply area. A conjunctive water source approach could be adopted through borehole supplementation to boost the quantity of water in the sectional reservoirs. This will enhance the autonomy of the reservoirs from the central waterworks. For effectiveness and enhanced delivery, a semi-autonomous Local Water Management Authority (LWMA) with distinct management that could fast-track response to the needs of the consumers should be established for each WSA. The implication of this arrangement is that the activities of the EKSWC shall be streamlined to focus on policy formulation, provision of guidelines and monitoring while strengthening the role and enhancing the operational capacity of LWMAs. The capacity of the LWMAs must be enhanced for revenue generation and accountability. In addition, for resource mobilization and monitoring, Water Users Association (WUA) should be established in each WSA. WUA shall be involved in mobilizing the community for self-help projects in addition to training community-based maintenance workers for water facilities that can be maintained through self-help initiatives. In general, government must encourage the development of local capacity that could enhance neighborhood water security, prompt reportage and token equity contribution towards reservoirs and system maintenance.

The long term desire of water supply system in the city should be to ensure that every household is connected to the piped water system. Efforts should therefore be made to bring piped water close to the homes. To ensure that most households are accessed to safe water, it is urgent for the Corporation to expand piped water network to the hitherto un-served transitional zone and the urban periphery. However, at the interim, it is proposed that no household should travel more than 200 meters before obtaining piped water. Water rationing is a manifestation of poor service delivery. Consumers must have access to uninterrupted supply of water. The success in this direction would however be largely determined by the efficiency of EKWSC. The LWMAs should therefore ensure ceaseless flow of water from pipes, regular maintenance of the system and quick response to leakages.

It is obvious that the only existing water-works (Ureje water-works) can no longer meet the water demand of the growing population of Ado-Ekiti even at full capacity. However, this inadequate supply from this source is still bedeviled with problems such as leakages, wastages and inadequate system servicing that result into under utilization of existing capacity. A general overhauling of EKSWC is required to mitigate these problems. For example, there is an urgent need to repair, re-work, re-engineer, and possibly re-reticulate the water system to forestall leakages.

Wastage from water users could also be reduced through aggressive sensitization programs by the Corporation. Such approach is expected to lead to attitudinal rebirth of the citizens on the usage of water. Pricing mechanism is another formidable tool to eliminating wastage. There is the tendency to reduce wastage if households are made to pay for water usage. In realization of the various problems associated with the introduction of meter especially its financial implication, we wish to suggest that at the interim, household size and other household characteristics should be used to determine cost of water consumption. Following successful sensitization and having operated the "user pays principle" for a considerable length of time, say five (5) years, we propose the introduction of meter.

Overcrowding that was observed around public water facilities could be attributed to the inadequacy of existing number of faucets. It should be noted that in terms of quality consideration, household connection is preferred. However, at this stage of development in Ado-Ekiti, fauceting of water cannot yet be discouraged rather the existing ones need to be coordinated and improved upon. To ensure adequate number of faucets, we suggest that government should take a census of each neighborhood in the city with the aim of determining the required number of faucet per neighborhood. In addition to the absolute population figure, the number of faucets to be established should take into consideration the characters of the population. In view of the limitations posed by water fauceting, it is proposed that government should wipe away faucets and legislate on the need for household connection in 2015.

\section{Appendix A:}

Research Variables Used in the Assessment of a Water Agency in a Rapidly Urbanizing City in Nigeria

1) Main Source of Domestic Water used by Household

2) Access to Improved Source of Domestic Water 
3) Adequacy of Supply from the Main Source

4) Household Preferred Domestic Water Source

5) Quantity of Water used per Person per Day

6) Supply from Ekiti State Water Corporation

7) Service Delivery Rating of Ekiti State Water Corporation

8) Payment for Service Delivery by Ekiti State Water Corporation

9) Average Monthly Payment to Ekiti State Water Corporation

10) Metering

11) Meter Reading

12) Billing

13) Adequacy of Supply of Ekiti State Water Corporation

14) Quality of Water from Ekiti State Water Corporation

15) Frequency of Pumping of Water by Ekiti State Water Corporation

16) Notices from Ekiti State Water Corporation

17) Response to Leakages

18) Adequacy of Public (Street) Standpipes

19) Appropriate Location/Distribution of Public (Street) Standpipes

20) Education Level

21) Occupation/Profession

22) Annual Income

\section{References}

Abumere, S. I. (1984). Population Distribution Policies and Measures in Africa South of the Sahara: A Review. Population and Development Review, 7(3) 421 - 433.

Arimah, B. C. (1995). Market Segmentation and the Impact of Landfills on Residential Property Values: Empirical Evidence from an African City. Netherlands Journal of Housing and the Built Environment, 10(2), $157-171$.

Ademola, A and Afeikhena, J. (2006). Utility privatization and the poor: Nigeria in focus. HBS Global Issues (12)

Adoga, O. (2006). Nigerian Water Policy and Law: A Need for Global Compliance. http://www.martindale.com/natural-resources-law/article-240640.html

AQUASTAT-FAO. (2010). Country Fact Sheet, Nigeria. http://www.fao.org/nr/aquastat.

Cairncross S. (1990). Water Supply and the Urban Poor. In Hardoy J. E et al (Eds), The Poor Die Young. $1^{\text {st }}$ Edition, Earthscan Publications, London, 109 - 126, ISBN: 132800.

Dada O; Okuofo C and Yussuf Z.I. (1990). The relationship between chlorine residual and bacteriological quality of tap water in the water distribution system of Zaria. Savannah, 2(1), 95-102.

Ebisemiju, F. S. (1993). Ado Ekiti Region: Hydrology and Surface Water Resources. Ado Ekiti Region - A Geographical Analysis and Master Plan. In F. S Ebisemiju (Eds), $1^{\text {st }}$ Edition, Alpha Prints, Ado Ekiti, Nigeria, 27 - 30. ISBN 978-028-466-4.

Ekiti State Department of Population Activities. (2004). Population Projections by Towns and Villages (2000 2005), Governor's Office, Ado-Ekiti, Nigeria.

Fadipe A. A and Adeduro A. (1993). Ado Ekiti Region: Geology and the Mineral and Groundwater Resources. Ado Ekiti Region - A Geographical Analysis and Master Plan. In Ebisemiju F. S Eds). $1^{\text {st }}$ Edition, Alpha Prints, Ado Ekiti, 15 - 20. ISBN 978-028-466-4.

Fasakin, J.O. (2000). Willingness to Pay for the Services of Commercial Motorcycle in Akure, Nigeria. Cities, 17:447-452.

Fasakin, J.O. (2001). Some factors affecting daily profits of commercial motorcycles in Akure, Nigeria, Transport Policy 8, 63-69.

Hall, D. (2006). Water and Electricity in Nigeria. A Report commissioned by Public Services International (PSI). www.world-psi.org.

Franceys, R. (1993). Improved access to urban water services in Uganda, Proceedings of the ICE - Municipal Engineer, 162(3), 165-170. 
Kalbermatten J.M. (1999). Should We Pay for Water? And if so, How? Urban Edge, Winter 1999 Edition, 14-15.

Stiles, G. (1996). Demand-side Management, Conservation, and Efficiency in the Use of Africa's Water Resources, Water Management in Africa and the Middle East, IDRC, Canada.

Sullivan, C.A., Meigh, J.R., Giacomello, A.M., Fediw, T., Lawrence, P., Samad, M., Mlote, S., Hutton, C., Allan, J.A., Schulze, R.E., Dlamini, D.J.M., Cosgrove, W., Delli Priscoli, J., Gleick, P., Smout, I., Cobbing, J., Calow, R., Hunt, C., Hussain, A., Acreman, M.C., King, J., Malomo, S., Tate, E.L., O’Regan, D., Milner, S., Steyl, I. (2003). The Water Poverty Index: Development and Application at the Community Scale. Natural Resource Forum, 27: 189-199.

UN. (2002). Facts about Water. Fact Sheet, Johannesburg Summit 2002. Johannesburg, South Africa www.un.org/jsummit/html/media_info/.

UNDP. (1998). Nigerian Human Development Report 1998, UNDP, Lagos, Nigeria.

UNEP. (2002). GEO 3 at a Glance-Freshwater. Our Planet, 3(2), 18, Nairobi, Kenya.

Urban Age. (1993). The changing Nature of Infrastructure. Urban Infrastructure Issue, 1(3), 13 - 20, The World Bank, Washington D.C.

WHO and UNICEF JMP. (2010). Progress on Sanitation and Drinking Water: 2010 Update, WHO, Geneva. ISBN 9789241563956.

WHO and UNICEF JMP. (2004). Meeting the MDG Drinking Water and Sanitation Target: A Mid-Term Assessment of Progress, WHO, Geneva. ISBN 9241562781.

World Bank. (1994). World Development Report, The World Bank, Washington D.C.

Table 1. Definitions of Research Variables

\begin{tabular}{lll}
\hline S/N & Variable Code & Definition Of Variable \\
1 & PERFORM & Performance of supply from EKSWC \\
2 & PAY & Payment to EKSWC \\
3 & BILL & Billing \\
4 & ADE-SUPPLY & Adequacy of supply from EKSWC \\
5 & FRE-PUMP & Frequency of pumping of water from EKSWC \\
6 & NOTICE & Notices from EKSWC \\
7 & RE-LEAK & Response to leakages \\
8 & A-TAP & Adequacy of public standing taps \\
9 & L-TAP & Appropriate location or distribution of standing pipes \\
\hline
\end{tabular}

Source: Fieldwork, 2007

Table 2. Correlation Matrix of Performance Variables for Ekiti State Water Corporation

\begin{tabular}{|c|c|c|c|c|c|c|c|c|}
\hline VARIABLES & PAY & BILL & $\begin{array}{l}\text { ADE-SU } \\
\text { PPLY }\end{array}$ & $\begin{array}{l}\text { PRE-PU } \\
\text { MP }\end{array}$ & NOTICE & $\begin{array}{c}\text { RE-LE } \\
\text { AK }\end{array}$ & A-TAP & L-TAP \\
\hline PAY & 1.000 & 0.014 & -0.200 & -0.067 & -0.042 & -0.051 & -0.138 & -0.093 \\
\hline BILL & & 1.000 & -0.136 & -0.027 & -0.058 & -0.098 & -0.140 & -0.087 \\
\hline $\begin{array}{l}\text { ADE-SUPPL } \\
\text { Y }\end{array}$ & & & 1.000 & 0.440 & 0.272 & 0.303 & 0.385 & 0.329 \\
\hline FRE-PUMP & & & & 1.000 & 0.280 & 0.620 & 0.329 & 0.356 \\
\hline NOTICE & & & & & 1.000 & 0.415 & 0.298 & 0.329 \\
\hline RE-LEAK & & & & & & 1.000 & 0.285 & 0.313 \\
\hline A-TAP & & & & & & & 1.000 & 0.573 \\
\hline L-TAP & & & & & & & & 1.000 \\
\hline
\end{tabular}

Source: Fieldwork, 2007 
Table 3. Pooled regression analysis result for performance variables

\begin{tabular}{|c|c|c|c|c|c|c|c|c|}
\hline Zone & \multicolumn{2}{|c|}{ City-Wide } & \multicolumn{2}{|c|}{ City Core } & \multicolumn{2}{|c|}{ Transitional Zone } & \multicolumn{2}{|c|}{ Urban Periphery } \\
\hline Variable & $\begin{array}{l}\text { Reg. } \\
\text { Coff. }\end{array}$ & $\begin{array}{c}\text { Abs. } \\
\text { t-Value }\end{array}$ & $\begin{array}{l}\text { Reg. } \\
\text { Coff. }\end{array}$ & $\underset{\text { t-value }}{\text { Abs. }}$ & $\begin{array}{l}\text { Reg. } \\
\text { Coff. }\end{array}$ & $\underset{\text { t-value }}{\text { Abs. }}$ & $\begin{array}{l}\text { Reg. } \\
\text { Coff. }\end{array}$ & Abs t-value \\
\hline In PAY & $0.402^{\mathrm{xx}}$ & 3.961 & $3.367^{\mathrm{xxx}}$ & 0.00 & 0.098 & -7.459 & -0.098 & -7.459 \\
\hline In BILL & $-0.318^{\mathrm{xx}}$ & -3.078 & 0.000 & 0.00 & -0.888 & -61.694 & -0.888 & -61.694 \\
\hline $\begin{array}{l}\text { In } \\
\text { ADE-SUPPLY }\end{array}$ & 0.009 & 0.79 & $-6.649^{x}$ & 0.00 & 1.043 & 46.501 & 1.043 & 46.501 \\
\hline In FRE-PUMP & 0.384 & 3.228 & $-5.460^{\mathrm{x}}$ & 0.00 & 0.192 & 13.877 & 0.192 & 13.877 \\
\hline In NOTICE & -0.212 & -2.018 & 5.094 & 0.00 & 0.306 & 16.020 & 0.306 & 16.020 \\
\hline In RE-LEAK & -0.216 & -2.298 & $-2.402^{\mathrm{xx}}$ & 0.000 & -0.363 & -39.237 & -0.363 & -39.237 \\
\hline In A-TAP & 0.305 & 2.659 & $5.659^{\mathrm{xx}}$ & 0.000 & 15.283 & 407979.1 & 15.283 & 407979.1 \\
\hline In L-TAP & 0.153 & 1.382 & 11.785 & 0.000 & 0.767 & 32.038 & 0.767 & 32.038 \\
\hline Constant & \multicolumn{2}{|c|}{$0.332^{* *}$} & \multicolumn{2}{|c|}{$0.196^{* * * *}$} & \multicolumn{2}{|c|}{$3.21 * * * *$} & \multicolumn{2}{|c|}{$0.196^{* * * *}$} \\
\hline $\mathbf{R}$ & \multicolumn{2}{|c|}{0.927} & \multicolumn{2}{|c|}{1.000} & \multicolumn{2}{|c|}{1.000} & \multicolumn{2}{|c|}{1.000} \\
\hline $\mathbf{R}^{2}$ & \multicolumn{2}{|c|}{0.860} & \multicolumn{2}{|c|}{1.000} & \multicolumn{2}{|c|}{1.000} & \multicolumn{2}{|c|}{1.000} \\
\hline Adjusted $R^{2}$ & \multicolumn{2}{|c|}{0.807} & \multicolumn{2}{|c|}{1.000} & \multicolumn{2}{|c|}{0.999} & \multicolumn{2}{|c|}{0.999} \\
\hline F-Ratio & \multicolumn{2}{|c|}{$16.120++++$} & \multicolumn{2}{|c|}{$4.1 \mathrm{E}+14++++$} & \multicolumn{2}{|c|}{$5252.731++++$} & \multicolumn{2}{|c|}{$5252.731++++$} \\
\hline $\mathbf{N}$ & \multicolumn{2}{|c|}{1,200} & \multicolumn{2}{|c|}{600} & \multicolumn{2}{|c|}{420} & \multicolumn{2}{|c|}{180} \\
\hline
\end{tabular}

Source: Fieldwork, 2007

$\ln$ is natural logarithm **** Significant at 0.000 alpha level (one-tail test)

$* * *$ Significant at 0.001 alpha level (one-tail test)

**Significant at 0.01 alpha level (one-tail test)

* Significant at 0.05 alpha level (one-tail test)

++++ F-ratio is significant at 0.000 level 


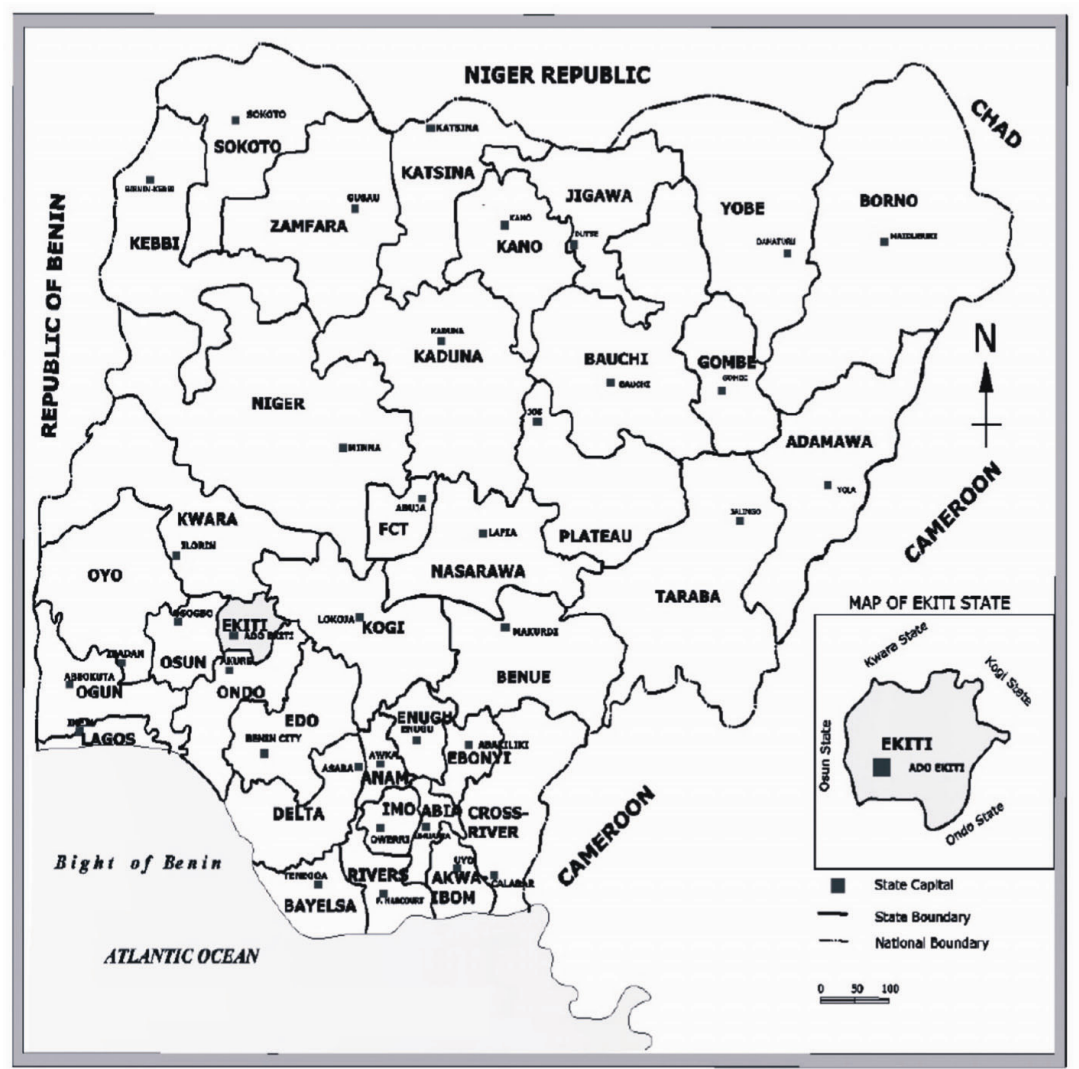

Figure 1. Ekiti State in Nigeria

Source: Field Work, 2007

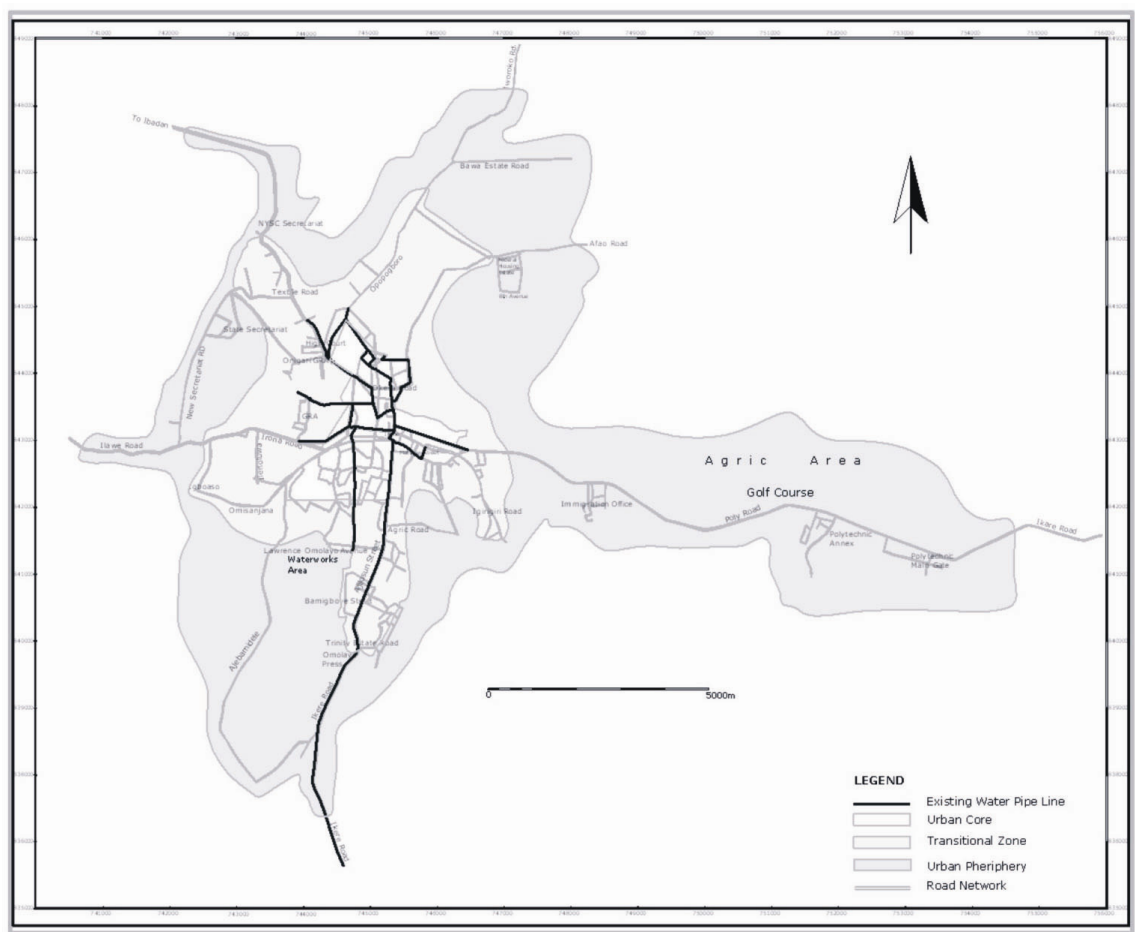

Figure 2. Piped water network in Ado-Ekiti residential zones - Network is largely restricted to the city core Source: Fieldwork, 2007 